\title{
A CORRELATION BETWEEN VOCABULARY AND SENTENCE STRUCTURE MASTERY TOWARDS READING COMPREHENTION OF PRIVATE UNIVERSITY STUDENTS IN WEST JAKARTA
}

\author{
Julyanta br Sitepu \\ Foreign Language High School (STIBA) IEC Bekasi, Indonesia \\ E-mail: bekasi201@gmail.com
}

\begin{abstract}
APA Citation: Sitepu, J.B, (2018). A Correlation between Vocabulary and Sentence Structure Mastery towards Reading Comprehension of Private University Students in West Jakarta. Journal of English Language and literature, 3(2), 11-19.doi: 10.37110/jell.v3i2.49.
\end{abstract}

Received: 15-07-2018

Accepted: 01-08-2018

Published:01-09-2018

\begin{abstract}
The research is conducted to prove a correlation between vocabulary and sentence structure mastery towards reading comprehension of private university students. The methodology used in this research is a survey of regression and correlation analysis which relates between the data and correlation between vocabulary and sentence structure mastery towards students' reading comprehension. The research uses three variables, two independent variables (vocabulary and sentence structure mastery), and one dependent variable (reading comprehension). The data is collected by using vocabulary, sentence structure and reading tests. The research found that: 1) There is a significant correlation between vocabulary and sentence structure mastery towards students' reading comprehension, proven by the result of Sig. $0.000<0.05$ and $F_{\text {-test }}=15.011 .2$ ). There is a significant correlation between vocabulary mastery towards students' reading comprehension, proven by the result of Sig. $0.008<0.05$ and $\mathrm{t}_{\text {-test }}=$ 2.744. 3). There is a significant correlation between sentence structure mastery towards students' reading comprehension, proven by the result of Sig. $0.011<0.05$ and $\mathrm{t}_{\text {-test }}=2.617$.

Keywords: Vocabulary Mastery, structure Mastery, Reading Comprehension.
\end{abstract}

\section{INTRODUCTION}

English is one of the most challenging subjects for the students in university since it is a foreign language in Indonesia. Some factors that make English challenging are; 1) Students' vocabulary mastery is low. For that reason, the students are not confident to express their opinion in English. 2)
Sentence structures in English are different from the sentence structures in Indonesian. For examples, sentence structures in Indonesian uses the same sentence structures for past, present, and future tenses. In English, tenses use different forms of verbs for past, present, and future tenses. 3) The 
A Correlation between Vocabulary and Sentence Structure Mastery towards Reading Comprehension of Private University Students in West Jakarta.

students have limited opportunities to practice their English in their everyday life activities.

Vocabulary is one of the most important components of a language in order to communicate with people both for speaking and for writing. To communicate well in English, the students have to use proper vocabulary in certain situations to express their ideas. Therefore, vocabulary mastery is a mandatory for the students. Hiebert and Kamil (2005:3) said "Failure to distinguish among the different kinds of vocabulary can lead to confusion and disagreement... vocabulary is the knowledge of meanings of words ". Hence, the students have to build their vocabulary to improve their skill of reading comprehension.

Besides the vocabulary mastery, the students also have to learn how to construct sentences using correct sentence structures. Their ability to use sentence structures properly will help them to read and understand paragraphs in English better. Without the sentence structure or grammar mastery, the students will fail to understand materials they read. Ohsima and Hogue (1988:155) stated, "A sentence is a group of words that you use to communicate your ideas. Every sentence is formed from one or more clauses and expressed a complete thought". When the words are not constructed correctly, it will be confusing and difficult to understand.

Reading is also an important activity in process of language learning since the students in universities have to read many references in English. For that reason, the students are required to master the reading comprehension skill. Reading comprehension is about comprehending an idea, thought, or story of a text. To improve the students' reading comprehension skill is important in teaching learning process. Reading text also gives the students opportunities study not only reading comprehension, but also many other aspects of language learning gradually. Jeremy Harmer (1998:68) said, "Reading texts also provide opportunities to study language: vocabulary, grammar, punctuation, and the way we construct sentences, paragraphs and texts".

The students can start reading simple sentences and continue to read more complex sentences after they have better understanding about the text they read. As Murni Djamal and friends (2006:4) wrote, "Improving reading skill sometimes depends on the ability of the reader to handle a sentence or a passage. Simple sentences are easy to understand, but compound and complex sentences need strategies to understand the author's message".

This research is essential to help the students to improve their vocabulary and structure mastery as well as their reading comprehension skill.

Reading is a receptive skill and it is about interpreting information in the written text. The readers have to be able to grasp messages that the writer intended to convey. Sanggam Siagian (2008:3) said, "The receptive written language skill is called 
reading. It is the skill of a reader or a group of readers to interpret information transferred by a writer". Reading also involves a dynamic process. As David Nunan (1992:70) stated, "Reading is a dynamic process in which the text elements interact factors outside the text". Meanwhile Jeremy Harmer, (1991:190) said, "Reading is an exercise dominated by the eyes and the brain. The eyes receive messages and the brain then has to work out the significance of these messages."

The most important process of teaching is achieving the objective, and the objective of teaching is to make the students able to comprehend something through their own experiences. Elizabeth Walter wrote in the Cambridge Advanced Learner's Dictionary "Comprehension is the ability to understand completely and be familiar with a situation, facts, etc." Arif Sukadi Sadiman (1946:109) described, "Comprehension is an ability of someone to interpret, paraphrase, translate, and state information he/she gets with his/her own words".

Based on the definition above, comprehension is the ability to understand concept of a certain material or issue and able to reconstruct it without changing the meaning. Reading comprehension is related to the ability of understanding the information found in the written text and also comprehending message given. Francoise Grellet (1999:3) said, "Understanding a written text means extracting the required information from it as efficiently as possible".
H.G. Tarigan (1986:117) wrote, "The main objective of reading comprehension is to seek answers to questions found in the written texts". Furthermore, Samsu Somadoyo (2011:7) stated, "Reading comprehension is a complex intellectual process that has two main aspects, understanding the meaning of the words and the ability to think about the verbal concept". Based on the explanation above, the readers actively respond and process the information given in the text in order to comprehend the messages written by the author.

Vocabulary plays an important role in the successfulness of communication. Whether the communication runs effectively and efficiently, it depends on the vocabulary chosen at the time of speaking. People who know how to use appropriate vocabulary in the correct contexts will attract listeners. They speak smoothly and communicatively to avoid the boredom. Through the words spoken, people are able to expresses their thought, feeling and ideas. Harmer (1991:153) said, "If language structures make up the skeleton of language, then it is the vocabulary that provides the vital organs and the flesh."

The more vocabulary someone acquires, the easier he/she expresses the ideas. It also helps him/her to comprehend the written texts without having much problem. H.R. Tarigan (1986:2) stated, "The quality of language acquisition is related to the quantity and quality of 
A Correlation between Vocabulary and Sentence Structure Mastery towards Reading Comprehension of Private University Students in West Jakarta.

vocabulary mastery". Therefore, vocabulary building without doubt is necessary for the students to make them able to participate more in using English.

The most important part of learning foreign languages is knowing the sentence structures well. Using the correct sentence structures will make the communication run smoothly and effectively. The messages being delivered by both speaker and writer will be through to listeners or readers with minimum problems.

A sentence structure is a group of words which at least has one subject and one verb with meaningful units. Subject of the sentence is the topic being discussed. It can be people, things, places, or activities. Meanwhile, the verb is an activity being done by the subject of the sentence. Cambridge Advanced Learner's Dictionary explains, " $A$ sentence is a group of words, usually containing a verb, which expresses a thought in the form of a statement, question, instruction or exclamation and starts with a capital letter when written". Oshima and Hogue (1998:157) said, "A sentence is a group of words that you use to communicate your ideas. Every sentence is formed from one or more clauses and expresses a complete thought".

From the definition given above, it shows how essential the sentence structure mastery is for the students in campus. With sufficient sentence structure mastery, they are able to comprehend the written texts much better. Thus, the students 'participation in learning English will increase.

\section{METHOD}

The research will use the methodology of survey with correlational analysis. Jack R. Fraenkel dan Norman E. Wallen (2007:335) said, "In a simple form, correlational research investigates the possibility of relationships between only two variables, although investigations of more than two variables are common". The data and information are collected from respondents in a private university in west Jakarta by giving respondents tests.

There will be three variables used in this reseach. The variables are: 1). Vocabulary mastery (X1). 2). Sentence structure mastery (X2). 3). Reading comprehensiond (Y). Vocabulary mastery is the ability of knowing, understanding, and using words appropriately and correctly when listening, speaking, reading, and writing in a certain language. The data is collected by giving a vocabulary test in the form of multiple choices. The sentence structure mastery is an ability to use sentence or grammar patterns correctly in speaking or writing. The grammar test will be given to the respondents to collect the data needed. The test is about verb tenses and sentence patterns (simple, compound, and complex sentences).

Reading comprehension is the ability to grasp the information and fathom the meaning of the author's messages given in the written texts. The reading comprehension test is 
about reading passages with multiple choice questions. The test questions are main ideas of the text, information details, unstated detail information, and vocabulary in context.

This research uses the formula of correlations to test the validity of the instruments. To validate the questions, the research will use Pearson Product Moment Correlation in Anas Sudijono (1987:176). To test the level of significant for the correlation between the vocabulary and sentence structure mastery towards reading comprehension in this research will also use Analysis Regression in SPSS program.

\section{RESULTS AND DISCUSSION}

The research findings are obtained from the variables of the instruments tested, reading comprehension (Y), vocabulary mastery (X1), and sentence structure mastery (X2). Each instrument consists of 30 questions.

\section{Reading Comprehension ( $Y$ )}

The data of reading comprehension are collected from 66 university students as the samples of the research. Minimum score is 60 , maximum score is 95 , mean is 78.94 , median 80.00 , mode 80 and standard deviation is 8.837 .

Table1. Reading Comprehension Table

\begin{tabular}{|c|c|c|}
\hline \multicolumn{3}{|c|}{ Statistics } \\
\hline \multicolumn{3}{|c|}{ Reading Comprehension } \\
\hline \multirow{2}{*}{$\mathrm{N}$} & Valid & 66 \\
\hline & Missing & 0 \\
\hline \multicolumn{2}{|c|}{ Mean } & 78.94 \\
\hline \multicolumn{2}{|c|}{ Median } & 80.00 \\
\hline \multicolumn{2}{|c|}{ Mode } & 80 \\
\hline \multicolumn{2}{|c|}{ Std. Deviation } & 8.837 \\
\hline \multicolumn{2}{|c|}{ Minimum } & 60 \\
\hline \multicolumn{2}{|c|}{ Maximum } & 95 \\
\hline
\end{tabular}

\section{Vocabulary Mastery (X1)}

The data of vocabulary mastery is obtained from 66 university students. Minimum score is 60 , maximum score is 95 , mean is 80.38 , median 80.00 , mode 80 and standard deviation is 9.336 . 
A Correlation between Vocabulary and Sentence Structure Mastery towards Reading Comprehension of Private University Students in West Jakarta.

Table2. Vocabulary Mastery

\begin{tabular}{|c|c|c|}
\hline \multicolumn{3}{|c|}{ Statistics } \\
\hline \multicolumn{3}{|c|}{ Vocabulary Mastery } \\
\hline \multirow{2}{*}{$\mathrm{N}$} & Valid & 66 \\
\hline & Missing & 0 \\
\hline \multicolumn{2}{|c|}{ Mean } & 80.38 \\
\hline \multicolumn{2}{|c|}{ Median } & 80.00 \\
\hline \multicolumn{2}{|c|}{ Mode } & 80 \\
\hline \multicolumn{2}{|c|}{ Std. Deviation } & 9.336 \\
\hline \multicolumn{2}{|c|}{ Minimum } & 60 \\
\hline \multicolumn{2}{|c|}{ Maximum } & 95 \\
\hline
\end{tabular}

Sentence Structure Mastery (X2)

The data of sentence structure mastery is taken from 66 university students. Minimum score is 60 , maximum score is 95 , mean is 80.23 , median 80.00 , mode 80 and standard deviation is 9.705 .

Table3. Sentence Structure Mastery

\begin{tabular}{|c|c|c|}
\hline \multicolumn{3}{|c|}{ Statistics } \\
\hline \multicolumn{3}{|c|}{ Sentence Structure Mastery } \\
\hline \multirow{2}{*}{$\mathrm{N}$} & Valid & 66 \\
\hline & Missing & 0 \\
\hline \multicolumn{2}{|c|}{ Mean } & 80.23 \\
\hline \multicolumn{2}{|c|}{ Median } & 80.00 \\
\hline \multicolumn{2}{|c|}{ Mode } & 80 \\
\hline \multicolumn{2}{|c|}{ Std. Deviation } & 9.705 \\
\hline \multicolumn{2}{|c|}{ Minimum } & 60 \\
\hline \multicolumn{2}{|c|}{ Maximum } & 95 \\
\hline
\end{tabular}

Table4. Multiple Coefficient Correlation Test Variable X1 and X2 towards Y. 


\begin{tabular}{|l|r|r|r|r|}
\hline \multicolumn{5}{|c|}{ Model Summary $^{\mathbf{b}}$} \\
\hline Model & $\mathrm{R}$ & $\mathrm{R}$ Square & $\begin{array}{c}\text { Adjusted R } \\
\text { Square }\end{array}$ & $\begin{array}{r}\text { Std. Error of } \\
\text { the Estimate }\end{array}$ \\
\hline 1 & $.568^{\mathrm{a}}$ & .323 & .301 & 7.387 \\
\hline $\begin{array}{l}\text { a. Predictors: (Constant), Vocabulary Mastery, Sentence Structure } \\
\text { Mastery }\end{array}$ \\
\hline
\end{tabular}

Table5. The Result of Level Significant of Coefficient Regression Test Variable $\mathrm{X} 1$ and $\mathrm{X} 2$ towards $\mathrm{Y}$.

\begin{tabular}{|l|l|r|r|r|r|r|}
\hline \multicolumn{7}{|c|}{ ANOVA $^{\text {a }}$} \\
\hline Model & $\begin{array}{c}\text { Sum of } \\
\text { Squares }\end{array}$ & Df & $\begin{array}{c}\text { Mean } \\
\text { Square }\end{array}$ & F & Sig. \\
\hline \multirow{4}{*}{1} & Regression & 1638.181 & 2 & 819.090 & 15.01 & $.000^{\mathrm{b}}$ \\
\cline { 2 - 7 } & Residual & 3437.577 & 63 & 54.565 & & \\
\cline { 2 - 7 } & Total & 5075.758 & 65 & & & \\
\hline \multicolumn{2}{|l|}{ a. Dependent Variable: Reading Comprehension } \\
\hline \multicolumn{2}{|l|}{ b. Predictors: (Constant), Vocabulary Mastery, Sentence Structure Mastery } \\
\hline
\end{tabular}

Table6. The Result of Multiple Regression Test Variable X1 and X2 towards Y.

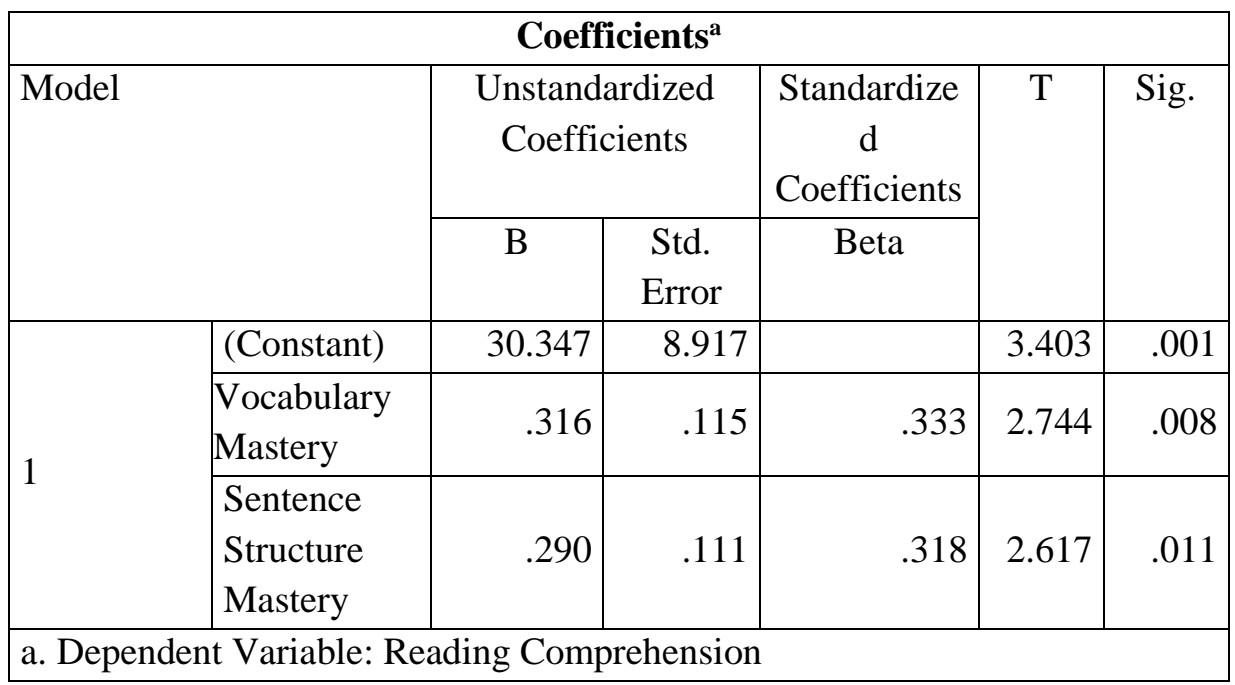


From the table 5 above, the correlation between vocabulary and sentence structure mastery towards reading comprehension is significant. Ho is rejected and Hi is accepted. It is proven by the score of Sig. $0.000<$ 0.05 and $\mathrm{F}_{\text {-test }}=15.011$.

Meanwhile, the multiple regression linearity shows that $\hat{Y}=$ $30.347+0.316 \mathrm{X}_{1}+0.290 \mathrm{X}_{2}$. It means when the score of one variable, vocabulary or sentence structure mastery, increases about X1 $=0.316$ and $\mathrm{X} 2=0.290$, it will give a significant contribution towards reading comprehension.

From table 6 above, it shows the correlation between vocabulary mastery towards reading comprehension is significant. Ho is rejected and $\mathrm{Hi}$ is accepted. It is proven by the score of Sig. 0.008 < 0.05 and $\mathrm{t}_{\text {-test }}=2.744$. From table 4 also proves that vocabulary mastery correlates in contributing about $32.3 \%$ towards reading comprehension.

Furthermore, the variable vocabulary mastery towards reading comprehension will be tested using a formula below:

$\mathrm{R}^{2}=$ Score $\beta_{x 1 y} \times$ Partial Correlation Score $\left(r_{x 1 y}\right) \times 100 \%$

$\mathrm{R}^{2}=0.333 \times 0.499 \times 100 \%=16.62 \%$

From the calculation above, it is stated that the contribution of vocabulary mastery improves the reading comprehension about 16.62 $\%$.

Table 6 shows that the sentence structure mastery contributes significantly towards the reading comprehension. Ho is rejected and $\mathrm{Hi}$ is accepted. It is proved from the score of Sig. 0,011<0.05 and $t_{\text {test }}=2.617$.

The contribution of the variable of sentence structure mastery can be formulated as follows:

$\mathrm{R}^{2}=$ Score $\beta_{x 2 y} \times$ Partial Correlation Score $\left(r_{x 2 y}\right) \times 100 \%$ $\mathrm{R}^{2}=0.318 \times 0.492 \times 100 \%=15.64 \%$

From the calculation above, it can be interpreted that the contribution of sentence structure mastery will improve the reading comprehension about $15.64 \%$.

\section{CONCLUSION}

There is a significant correlation between vocabulary and sentence structure mastery towards reading comprehension. It is proven by the score of Sig. $0.000<0.05$ and $\mathrm{F}_{\text {-test }}=$ 15.011. The contribution is about $32.3 \%$. There is a significant correlation between vocabulary mastery towards reading comprehension. It is proven by the score of Sig. $0.008<0.05$ and $t_{\text {test }}=$ 2.744. It contributes about $16.62 \%$ The sentence structure mastery contributes significantly towards the reading comprehension. It is proven from the score of Sig. 0,011<0.05 and $t_{\text {test }}=2.617$. The contribution of sentence structure mastery will improve the reading comprehension about $15.64 \%$.

\section{BIBLIOGRAPHY}

Djamal, Murni et al. 2006. Improving Reading Skill in English for 
University Students. Jakarta: Kencana Media Group.

Fraenkel. R.J. \& Wallen. E. (2007). How to design and evaluate research in education. Sixth Edition. New York: McGraw-Hill.

Grellet, Francoise. 1999. Developing Reading Skill. New York: Cambridge University Press.

Hiebert, Elfrieda H. \& Michael L. Kamil. 2005. Teaching and Learning Vocabulary. London: Lawrence Erlbaum Associates, Publishers.

Harmer, Jeremy. 1998. How to Teach English. England: Longman. 1991. The Practice of English Language Teaching: Third Edition. New York: Longman Publishing.

Keraf, Gorys. 1991. Tata Bahasa Rujukan Bahasa Indonesia. Jakarta: Gramedia Widiasatya.

Nunan, David. 2007. What is This Thing Called Language. New York: Palgrave Macmillan.
Oshima, Alice \& Aan Hoque. 1998. Writing Academic English, Third Edition. New York: Addison Wesley Longman

Sadiman, Arif Sukadi. 1946. Beberapa Aspek Pengembangan Sumber Belajar. Cet.I. Jakarta: Mediyatama Sarana Perkasa.

Siagian, Sanggam. The English Paragraph. Jakarta: Graha Ilmu. 2008.

Somadoyo, Samsu. 2011. Strategi dan Teknik Pembelajaran Membaca. Yogyakarta: Graha Ilmu.

Sudijono, Anas. 1987. Pengantar Statistik Pendidikan. Jakarta: Raja Grafindo Persada Buchari Alma.

Tarigan, Henry Guntur.1986. Menulis sebagai Suatu Keterampilan Berbahasa. Bandung: Angkasa.

Walter, Elizabeth. 2008. Cambridge Advanced Learner's Dictionary. Cambridge. Cambridge University Press. 